Kaisa Haapakoski \& Leena Åkerblad

\title{
Realistinen optimismi ja toiveikkuus: ammatillisen kuntoutuksen osapuolten näköalat suomalaiseen työelämään
}

\begin{abstract}
Abstrakti
Tas Tässä artikkelissa tarkastelemme Kelan työllistymistä edistävän ammatillisen kuntoutuksen osapuolten kuvauksia suomalaisesta työelämästä. Keskitymme erityisesti työelämään liittyvien myönteisten näköalojen ja niissä esiintyvän optimismin analysointiin. Toivo ja optimismi ovat aiemmissa tutkimuksissa osoittautuneet merkityksellisiksi tekijöiksi työhön paluun prosesseissa. Aineiston muodostivat kuntoutujien, omaohjaajien ja työnantajien haastattelut (47 kappaletta). Kuntoutuksen kaikkien osapuolten puheesta tunnistettiin myönteisiä näköaloja ja erilaisia optimismin muotoja. Optimismia esiintyi suhteessa työhön osallistumisen rakenteellisiin reunaehtoihin, kuten työkulttuuriin ja muutospotentiaalin tunnistamiseen. Lisäksi painottuivat omakohtaiset suunnanmuutoksen mahdollisuudet. Erityisesti omaohjaajilla korostui myös osatyökykyisten asemaa koskeva huolipuhe. Osatyökykyisten asema polarisoituvilla työmarkkinoilla sekä tasavertaisen ja osallisuutta mahdollistavan työelämän rakentaminen olivat kaikille osapuolille keskeisiä kysymyksiä. Ammatillisen kuntoutuksen osapuolten optimismi tarkentuikin realistiseksi optimismiksi, jossa tulevaisuutta koskeva toiveikkuus on mahdollista, vaikka tavoitteiden saavuttamiseen vaikuttavat myös muutosta vaativat rakenteelliset reunaehdot.
\end{abstract}

\section{Johdanto}

Työelämän ulkopuolelle ja laidalle sijoittuu useita ryhmiä, joiden työmarkkina-asema ja muu elämäntilanne, kuten terveys ja taloudellinen toimeentulo, ovat heikkoja (esim. Leeman ym. 2018). Suomalaisen työelämän tilasta käydään paljon julkista keskustelua, mutta vähemmän on tutkittua tietoa siitä, miten erityisesti työelämän marginaalissa olevat näkevät tämänhetkisen työelämän. Työelämän tutkimuksessa onkin tärkeää ottaa huomioon myös huono-osaisten, pienituloisten ja pitkäaikaistyöttömien ryh- mät (Kirjoittajakollektiivi 2017). Tässä artikkelissa näemme, että työmarkkinoiden ja työelämän tutkimuksen kannalta erityisiin ryhmiin kuuluvat myös työkyvyltään heikommassa asemassa olevat. Heidän kohdallaan sairaudet, vammat ja elämäntilanteeseen liittyvät ristiriidat haittaavat työssä selviytymistä. Kelan ammatillisiin kuntoutuspalveluihin osallistuvat kuuluvat usein tämänkaltaiseen ryhmään.

Tässä artikkelissa tarkastelemme ammatillisen kuntoutuksen eri osapuolten kuvauksia suomalaisesta työelämästä. Analysoimme moninäkökulmaista haastatteluaineistoa, joka on 
kerätty Kelan työllistymistä edistävää ammatillista kuntoutusta (TEAK) koskevan tutkimuksen yhteydessä. Tutkimus on toteutettu osana Kelan laajempaa Muutos-hanketta (Kela 2015). TEAK-tutkimuksessa arvioitiin vuonna 2017 alkaneen Kelan työllistymistä edistävän ammatillisen kuntoutuksen toimivuutta (Haapakoski ym. 2020). Ammatillisen kuntoutuksen toimivuuteen liittyy se, miten kuntoutujan työkyky voi kohentua ja miten työolosuhteita voidaan muokata siten, että työssä selviytyminen olisi mahdollista. Lydellin ja kumppaneiden (2011) tutkimuksessa sairauksia ja työkykyongelmia kohdanneiden henkilöiden optimistiset ja toiveikkaat kuvaukset tulevaisuudesta ja työelämästä tukivat nopeaa työhönpaluuta. Hitaampaan työhönpaluuseen yhdistyivät puolestaan kuvaukset työelämään liittyvistä esteistä sekä epäröinti (emt.). Myös urasuunnittelussa ja oman alan etsimisessä toivolla on oma merkityksensä (esim. Hirschi ym. 2014). Santilli ja kumppanit (2017) toteavat, että toiveikas ja optimistinen suuntautuminen tulevaisuuteen saattaa olla työuralle sopeutumisen ja elämänlaadun kannalta hyvin kontekstikohtaista: toiveikkuudella voi olla merkitystä erityisesti ympäristöissä, joissa uravalinnat tehdään varhain ja sopeutumisen mahdollisuudet nähdään rajallisina. Tässä artikkelissa pyrimmekin tunnistamaan, millaisia työelämään liittyviä tulevaisuuden näköaloja suomalaisen ammatillisen kuntoutuksen osapuolilla esiintyy.

Osatyökykyisten työmarkkina-asema ja ansiotaso ovat laajojen vertailujen mukaan heikompia kuin väestöllä keskimäärin ja osatyökykyiset ovat muita useammin työttöminä. Tilastojen ja tutkimusten vertailu on kuitenkin haasteellista, koska seurantakäytännöt vaihtelevat. (Asplund \& Koistinen 2014, 100-110.) Työttömyys ja osatyökykyisyys esiintyvät usein päällekkäin (Laiho ym. 2010) ja osatyökykyisille suunnatut palvelut, kuten palkkatuet, tuettu työllistyminen, suojatyö ja ammatillinen kuntoutus, ovat usein yksittäisiä työelämään siirtymistä tukevia toimia (Asplund \& Koistinen 2014, 106). Kelan ammatillisen kuntoutuksen palveluihin pääsevät vain ne, joille kuntoutus hakuprosessin jälkeen myönnetään. Palveluja voidaan lain mukaan myöntää henkilöille, joiden työkyky on olennaisesti heikentynyt sairauden, vian tai vamman vuoksi. Käytännössä Kelan asiakkaiden sidos työelämään on usein kevyempi kuin työeläkekuntoutuksessa. Taustalla voi olla sairauden lisäksi esimerkiksi työttömyyttä, koulutusjaksoja ilman työkokemusta, pätkittäistä työhistoriaa, pitkiä sairauslomia tai määräaikaisia työkyvyttömyyseläkejaksoja. Kuntoutuspäätöksiä tehtäessä arvioidaan työkyvyn heikentymistä ja otetaan huomioon hakijan kokonaistilanne sekä opiskelukyky. (Laki Kansaneläkelaitoksen kuntoutusetuuksista ja kuntoutusrahaetuuksista 566/2005.)

Tämän artikkelin tarkoituksena on paikantaa kuntoutuspalvelussa (työllistymistä edistävä ammatillinen kuntoutus) osallisina olleiden kuntoutujien, työnantajien ja omaohjaajien näköaloja työelämään: millaisia nämä näköalat ovat ja miten ne suhteutuvat toisiinsa. Kiinnostuksen kohteena ovat erityisesti myönteiset näköalat työelämään sekä optimismin erilaiset muodot. Artikkelissa analysoidaan Kelan ammatilliseen kuntoutukseen liittyvää haastatteluaineistoa. Kelan työllistymistä edistävä ammatillinen kuntoutus (TEAK) korvasi vuonna 2017 aiemmat Kelan palvelut eli työkokeilun, työhönvalmennuksen ja mielenterveyskuntoutujien työhönvalmennuksen. Palvelu on jaettu kolmeen palvelulinjaan, joista lyhin kestää noin kolme kuukautta ja pisin 26 kuukautta. Palvelu koostuu alkujaksosta palveluntuottajan eli kuntoutusyksikön tiloissa sekä työkokeilu- ja työhönvalmennusjaksoista työpaikoilla. Palveluun osallistuville nimetään kuntoutusyksiköstä omaohjaaja, jonka tehtävänä on tarjota tukea ja olla säännöllisesti yhteydessä kuntoutujaan työkokeilun tai valmennuksen aikana. (Kela 2016.) Aiemman tutkimuksemme (Haapakoski ym. 2020) perusteella työllistymistä edistävään ammatilliseen kuntoutukseen osallistuneet olivat usein olleet pitkään työttömänä ja heillä oli monia työkykyä heikentäviä terveydellisiä ongelmia. 
Varsin suuri osa osallistuneista koki toimeentulonsa riittämättömäksi. Tässä artikkelissa tarkastellaan kuntoutujien, omaohjaajien sekä työkokeilu- ja valmennusjaksoihin osallistuneiden työnantajien kuvauksia työelämästä.

\section{Optimismi ja toivo}

Toivo on työhön palaamisen prosesseissa merkityksellistä (esim. Lydell ym. 2011; Porter ym. 2018 ). Toivoa ja optimismia voidaan pitää lähikäsitteinä (Youssef \& Luthans 2007), ja optimismi on ollut erityisesti psykologisen ja psykiatrisen kuntoutusta koskevan tutkimuksen kohde. Martin Seligmanin (1990) kehittämässä positiivisen psykologian tutkimussuuntauksessa optimismia ja pessimismiä tutkittiin niin sanotun opitun avuttomuuden ymmärtämiseksi. Myöhemmin psykologisessa tutkimuksessa on kehitetty erilaisia optimismia kuvaavia mittareita (esim. Scheier \& Carver 1985; Scheier ym. 1994; Snyder 2002).

Optimismiin on liitetty ajatus myönteisistä tulevaisuuden odotuksista ja pessimismiin puolestaan käsitys kielteisistä tulevaisuuden näkymistä. Vaikka sekä optimismin että pessimismin on aiemmin nähty kuvastavan samalle ulottuvuudelle asettuvia persoonallisuuden piirteitä, nähdään ne empiirisessä tutkimuksessa nykyisin toisistaan erillisinä ilmiöinä. Kronströmin ja kumppaneiden (2011) mukaan optimistisen ja pessimistisen ajattelutavan on todettu vaikuttavan toisistaan erillisinä esimerkiksi masennukseen liittyvään työkyvyttömyyden riskiin. Työhön palaamisen on nähty olevan yhteydessä juuri myönteiseen ajatteluun ja optimismiin (emt.). O'Connorin ja Cassidyn (2007) mukaan optimismin puute erottaa myös depression ja itsetuhoisuuden ilmiöitä toisistaan: masentuneisuudessa voi olla mahdollisuus tuottaa myönteistäkin tulevaisuusajattelua, vaikka kielteinen ajattelu olisi yhtä vahvaa kuin itsetuhoisten henkilöiden kohdalla. Optimismiin ja pessimismiin liittyvien empiiristen tutkimustulosten myötä onkin mahdollista ymmärtää, etteivät optimismi ja pessimismi edusta vastakkaisia ääripäitä tai vastakohtia. Sen sijaan ne voidaan ymmärtää toisistaan erillisinä, tulevaisuutta koskevien ajattelutyylien ja mielikuvien muotoina. Onkin perusteltua pitää optimismia ja myönteistä ajattelutapaa sekä pessimismiä omina erityislaatuisina tutkimuskohteinaan (vrt. Bryant \& Cvengros 2004). Olemme tässä artikkelissa kiinnostuneita erityisesti myönteisistä työelämän kuvauksista. Aineiston alustava luenta osoitti, etteivät kuntoutukseen osallistuneiden osatyökykyisten näköalat olleet heidän haastavasta työelämäasemastaan huolimatta selkeän pessimistisiä vaan niissä esiintyi toiveikkuutta.

Toivo on optimismin lähikäsite. Tutkimuksissa esiintyy erilaisia näkemyksiä siitä, miten optimismi, toivo ja toiveikkuus eroavat käsitteellisesti toisistaan. Youssefin ja Luthansin (2007) mukaan toivo eroaa optimismista erityisesti siten, että toivoon voi liittyä vaihtoehtoisia tulevaisuuksien ja tapahtumien kulkuun liittyvien "reittien" mahdollisuuksia. Tällöin toivo voi mahdollistaa myös tahdonvoiman ja päättäväisyyden elpymistä, sillä erilaisia reittejä on voitu ennakoida jo ennen vastoinkäymisiä. Lisäksi esteet ja ongelmat voidaan nähdä oppimisen mahdollisuuksina. Kaikkiaan toivoon liittyy joustavaa vaihtoehtoisuutta. Toivo kuvastuu myös sisäisenä ja itseohjautuvaa toimijuutta sisältävänä tapahtumana, jolloin vastoinkäymisten ulkoiset selitysmallit eivät ole erityisen keskeisiä (Youssef \& Luthans 2007; ks. myös Snyder 2002). Youssef ja Luthans (2007) esittävät myös, että optimismiin sisältyy usein ulkoisia selitysmalleja; esimerkiksi vastoinkäymisille nähdään olevan olemassa itsestä erillisiä syitä. Tällöin optimismin käsitteeseen liitetään mahdollisuus tilanne- ja kontekstitekijät huomioivasta myönteisyydestä. Sen kanssa voi yhtäaikaisesti esiintyä toiveikkuutta ja mielensisäistä joustavuutta, joka tukee tulevaisuuteen myönteisesti suuntautuvaa toimijuutta (Schneider 2001). Realistiseen optimismiin liittyykin Schneiderin (emt.) mukaan ympäristön ja tilannekohtaisten tekijöiden sekä ristiriitaisten tekijöiden huomiointia, 
mikä voi suojata epärealististen tavoitteiden asettamiselta (vrt. myös Youssef \& Luthans 2007). Realistisessa optimismissa korostuvat myös yksilön ja ympäristön välinen vuorovaikutus, herkkyys sille, mitä emme vielä tiedä sekä aktiivinen asenne elämää ja mahdollisuuksia kohtaan (Schneider 2001).

Toivoa on käsitelty laajasti myös filosofian parissa. Nykykeskusteluissa viitataan usein toivon standardimääritelmään, jossa toivon kohde on haluttava (desired) ja sen saavuttaminen on epävarmaa (Bloester \& Stahl 2017). Toiveikkuus (hopefulness) voidaan puolestaan ymmärtää fundamentaalisena toivon muotona, jolloin sillä ei ole välttämättä selkeää kohdetta vaan se voi ilmetä esimerkiksi yleisenä avoimuutena itselle lupaavien ja merkityksellisten mahdollisuuksien äärellä (vrt. emt.). Toivo ymmärretään länsimaisessa nykykulttuurissa usein myönteisenä, hyvään elämään kuuluvana piirteenä. Toivoon liittyvä filosofia sisältää kuitenkin monia erilaisia näkökulmia (emt.; Snyder 2000). Antiikin Kreikan mytologiassa toivo näyttäytyi epäluotettavana neuvonantajana ja kärsimyksen pitkittäjänä. Myös esimerkiksi stoalaisuudessa eteenpäin suuntautuva, luottavainen haluaminen ja toivo edustivat riippuvuutta ja ihmisen rajallisuutta (Kotkavirta 2000). Epärealistiset myönteiset odotukset voivat rikkoutua, mikä voi johtaa pettymyksiin. Epärealistisen toivon herättäminen saattaakin olla kuntoutuseettisesti vaikea ongelma. Esimerkiksi lääketieteen alalla toivon herättämistä pidettiin tietyssä vaiheessa "puoskarointiin" liittyvänä epälegitiiminä ilmiönä (Snyder 2000). Snyderin (emt.) mukaan osa lääketieteen tutkijoista ryhtyi kuitenkin radikaalisti puolustamaan myönteisten emootioiden merkityksellisyyttä toipumisprosesseissa.

Kuntoutuksen tutkimuksessa toivo on kuvastunut tekijänä, joka saattaa edesauttaa paranemista ja kuntoutumisen prosesseja. Tällöin toivo ymmärretään motivaation ja päättäväisyyden lisäksi eräänlaiseksi kuntoutushalun edellytykseksi (esim. Onken ym. 2007). Toivo rakentuu Russinovan (1999) mukaan vuorovaikutuksessa ja sen muodostuminen kuntoutuksessa edellyttää suhteita. Russinovan (emt.) tutkimuksessa kuntoutusammattilaisten kompetenssi rakentui erityisesti uskosta paranemisen potentiaaliin, kyvystä sietää epävarmuutta suhteessa tulevaisuuteen, motivaatioon tuottaa yhä parempia vaikutuksia sekä erilaisten toivoa herättävien tekniikoiden ja resurssien hallinnasta. Toivoon voi liittyä myös rohkaisua. Wongin (2015) mukaan rohkaisu on kielellistä ja symbolista ilmaisua, jonka avulla vahvistetaan määrätietoisuutta, luottamusta, inspiraatiota tai toivoa tilanteessa, jossa henkilö kohtaa haasteita tai jossa hänen potentiaalinsa ei ole vielä tullut esiin.

Kuntoutuspalvelut ovat sosiaalisesti muodostuvia tapahtumia. Työhönpaluun vaihtelevissa kertomuksissa kuntoutustyöntekijät voivat asettua eri rooleihin (Ståhl \& Edvardsson 2014). Kuntoutujilla voi puolestaan Porterin ja kollegoiden (2018) mukaan olla työelämään palaamiseen liittyviä pelkoja stigmasta. Kuntoutustyöntekijöiden myönteinen asenne, empatia ja aito kiinnostus kuntoutukseen osallistuvan tarpeita kohtaan ovat työhönpaluussa tärkeitä tekijöitä, kuten myös toivo sekä työskentelyyn liittyvä kokonaisvaltainen ote byrokraattisen otteen sijaan (emt.) Työelämään liittyvässä kuntoutuksessa olennaista ei kuitenkaan ole vain työntekijän tai terapeutin ja kuntoutujan välinen suhde vaan myös erilaiset työelämäsuhteet (Seing ym. 2015). Ammatillisen kuntoutuksen vaikuttavuuteen liittyy se, että osatyökykyisen, vammaisen tai sairauksia kohdanneen työhön integroituminen voi tapahtua ainoastaan työelämässä (Gustafsson ym. 2018). Tutkimuksissa ei kuitenkaan ole aina löydetty yhteyttä toivon ja kuntoutuksen tulosten, kuten työllistymisen välillä (Waynor \& Gill 2015). Ammatillinen kuntoutus onkin aina sidoksissa ympäristöön. Osatyökykyisille suunnattuun ammatilliseen kuntoutukseen liittyvä työelämäkonteksti on kuitenkin toistaiseksi varsin tutkimaton alue. Tällä on merkitystä myös palveluiden vaikuttavuuden arvioinnin kannalta. Osatyökykyisten palvelujen vaikutusten tutkimusta on pidetty ylipäätään hyvin vähäisenä (Asplund \& Koistinen 2014). 


\section{Tutkimuksen tavoite, aineisto ja menetelmät}

Tässä artikkelissa keskitymme työelämään liittyvien myönteisten eli optimismia ja toivoa sisältävien sekä muiden (ei-myönteisten) näköalojen laadulliseen erotteluun. Tavoitteena on selvittää, millaisia näköaloja ammatillisen kuntoutuksen osapuolilla on työelämään ja miten nämä näköalat suhteutuvat sekä toisiinsa että laajemmin osatyökykyisten asemaan työelämässä. Näköalalla tarkoitetaan perspektiiviä, joka rakentuu puhujan ottaessa sekä ajallisesti (menneisyys-nykyhetki-tuleva) että subjektiaseman osalta tietynlaisen puhuja-aseman työelämää kuvaillessaan. Subjektiasemat voivat yleisesti rakentua hyvin monella tavalla (vrt. Törrönen 2010). Analyysissa keskitymme erottelemaan, kuvaillaanko työelämää henkilön oman tulevaisuuden tai nykytilanteen osalta vai toisten - erityisesti osatyökykyisten - näkökulmaa painottaen.

Aineisto koostuu Kelan työllistymistä edistävää ammatillista kuntoutusta koskevan tutkimuksen (TEAK-tutkimus) yhteydessä kerätystä teemahaastatteluaineistosta. TEAK-tutkimuksen tehtävänä oli uuden palvelun arvioiminen, ja tutkimuksessa kerättiin useita erilaisia aineistoja kuntoutuksen eri osapuolilta. Tutkimukseen sisältyvissä teemahaastatteluissa käsiteltiin palveluun liittyviä kokemuksia ja palvelun toimivuutta. Tutkimuksessa haastateltiin palveluun osallistuneita työnantajia ( $\mathrm{n}=14+\mathrm{yksi}$ kirjallinen vastaus), kuntoutuspalvelun omaohjaajia ( $\mathrm{n}=18$, työelämää koskevia vastauksia 17) sekä palveluun osallistuneita kuntoutujia $(\mathrm{n}=15)$. Käytämme tekstissä termiä osatyökykyinen kuvaamaan laajasti työkykyyn ja työelämään liittyvien haasteiden kanssa eläviä henkilöitä sekä sanaa kuntoutuja kuvaamaan kuntoutuspalveluun osallistuneita, haastateltuja henkilöitä. Sanojen ei ymmärretä kuvaavan tässä juuri tiettyjä henkilöitä tai ilmiötä (vrt. Järvikoski 2013). Palveluun osallistuneet henkilöt eivät aina kokeneet itseään kuntoutujiksi. Käytämme tässä artikkelissa termejä kuntoutuja ja osatyö- kykyinen teknisistä syistä, lisäämään tekstin luettavuutta sekä helpottamaan analyysin ja tulosten kuvailua.

Haastatteluihin osallistui monipuolisesti erilaisia haastateltavia. Kuntoutujien haastattelut toteutettiin kasvokkain eri alueilla, pienissä kunnissa ja suuremmissa kaupungeissa. Työnantajien ja omaohjaajien haastattelut toteutettiin puhelinhaastatteluina. Kaikkiaan haastatteluja oli analyysissa mukana 47 (naisia 34 ja miehiä 13). Nauhoitetut haastattelut litteroitiin tekstiksi ja koodattiin Atlas.ti-ohjelmassa TEAK-tutkimusta varten. Tämän artikkelin analyysissa keskityttiin tarkastelemaan yhtä aineisto-osiota, jossa haastateltavilta tiedusteltiin, mitä he ajattelevat työelämästä Suomessa vuonna 2018. Vastaukset tähän kysymykseen erotettiin aineistosta analyysia varten. Lopullinen aineisto sisälsi 36 sivua puhujittain merkittyä tekstiä (riviväli 1,5, fonttikoko 12, Times New Roman).

Analyysi eteni vaiheittain lukemalla ja koodaamalla aineistoa. Ensin aineisto luettiin kokonaisuudessaan koodaamatta sitä. Tässä yhteydessä ilmeni, etteivät työelämän kuvaukset olleet erityisen pessimistisiä, vaan sisälsivät eri tavoin ilmaistua myönteisyyttä. Tämän jälkeen aineisto koodattiin erottelemalla ensiksi nykyhetkeen ja menneisyyteen sekä toiseksi tulevaisuuteen kytkeytyvä sisältö (ajallisuuteen kohdistuva analyysi). Seuraavaksi paikannettiin erityisesti optimistisia näköaloja, muita eli ei-myönteisiä näköaloja sekä näköalojen puuttumista. Koodauksessa huomioitiin haastateltavan ottama puhuja-asema: henkilökohtaisesti painottunut, toisen tai osatyökykyisen asemaa painottava (puhuja-asemaan kohdistuva analyysi). Koodit koottiin taulukkoon haastatteluittain. Tiivistetystä taulukosta 1 nähdään, miten koodit esiintyivät kuntoutuksen eri osapuolten eli kuntoutujien, omaohjaajien ja työnantajien puheessa. Koodausvaiheiden jälkeen osapuolten kuvauksista jäljitettiin toistuvia näköaloja. Tulkinta kohdistui siis erityisesti niihin sisältöihin, joita eri osapuolten kuvauksissa esiintyi runsaimmin ja toistuvasti. 
Taulukko1. Koodausten esiintyminen aineistossa

\begin{tabular}{|c|c|c|c|}
\hline \multirow[b]{2}{*}{ Työelämän näköala, koodauksen sisältö } & \multicolumn{3}{|c|}{$\begin{array}{l}\text { Haastattelujen osapuolet ja haastattelut, joissa sisältö } \\
\text { esiintyy }\end{array}$} \\
\hline & $\begin{array}{l}\text { Kuntoutujat } \\
\text { (15 kpl) }\end{array}$ & $\begin{array}{l}\text { Omaohjaajat } \\
\quad(17 \mathrm{kpl})\end{array}$ & $\begin{array}{l}\text { Työnantajat } \\
\text { (15 kpl) }\end{array}$ \\
\hline Naiset & 9 & 15 & 10 \\
\hline Miehet & 6 & 2 & 5 \\
\hline Yleinen tulevaisuuteen suuntautuva & 8 & 7 & 10 \\
\hline Optimistinen, henkilökohtaisesti painottunut & 5 & 1 & 5 \\
\hline Optimistinen, toisen asemaa painottava & 0 & 2 & 4 \\
\hline Optimistinen, osatyökykyisten asemaa painottava & 0 & 2 & 1 \\
\hline Optimistinen, muu, yleinen & 1 & 4 & 3 \\
\hline Ei myönteinen, henkilökohtaisesti painottunut & 6 & 3 & 0 \\
\hline Ei myönteinen, toisen asemaa painottava & 3 & 0 & 4 \\
\hline Ei myönteinen, osatyökykyisten asemaa painottava & 3 & 15 & 6 \\
\hline Ei myönteinen, muu, yleinen & 9 & 10 & 9 \\
\hline Näköalan puute - ei perspektiiviä & 2 & 0 & 0 \\
\hline
\end{tabular}

Seuraavaksi käymme läpi haastatteluissa mukana olleiden, Kelan työllistymistä edistävään ammatilliseen kuntoutukseen osallistuneiden osapuolten näköaloja ja nimeämme haastatteluissa esiintyneitä optimismin muotoja. Käsittelemme erikseen kuntoutujien, omaohjaajien ja työnantajien haastatteluja. Tekstissä esitetään haastattelusitaatteja, joista on poistettu täytesanoja ja joita on paikoitellen yleiskielistetty sekä haastateltavien anonymiteetin varmistamiseksi että asiasisällön luettavuuden parantamiseksi.

\section{Kuntoutujien optimismi}

Kuntoutujien työelämän kuvaukset olivat puhuja-asemaltaan useimmiten henkilökohtaisesti painottuneita, omakohtaisia. Kuntoutujien haastatteluissa esiintyi myös ainoana osapuolena näköalan kuvailun vaikeutta. Näköaloissa esiintyi erilaisia optimismin muotoja. Analyysissa tunnistettiin erityisesti omaan kompetenssiin kytkeytyvää optimismia (kompetenssioptimismi), struktuurien muuttamista vaativaa optimismia (muutosvaatimusoptimismi) sekä epävarmaa omakohtaista suunnanmuutosoptimismia (suunnanmuutosoptimismi). Kuntoutuspalveluun osal- listuneiden optimismi vaikutti hyvin henkilökohtaiselta, mutta samalla se oli selvästi kytköksissä erilaisiin työelämän rakenteisiin. Siinä tunnistettiin tiettyjä työelämään liittyviä rakenteellisia reunaehtoja, joiden puitteissa henkilökohtainen optimismi ja toiveikkuus mahdollistuivat.

Kompetenssioptimismia sisältävässä puheessa oma kyvykkyys, osaaminen ja asema työelämässä nähtiin riittävinä suhteessa työelämässä "hyvin pärjääviin" ryhmiin. Seuraavassa aineisto-otteessa tämä "pärjäävien" ryhmä määrittyy sukupuolittuneeksi sekä iän ja itsetunnon osalta erilaiseksi, kuin mihin haastateltava on itsensä aikaisemmin identifioinut ("nuoret miehet"). Nyt haastateltava kuvaa kompetenssiaan myönteisellä ja tasavertaisuutta korostavalla tavalla suhteessa työelämässä "pärjääviin":

- - että semmoset, kovassa itsetunnossa olevat nuoret miehet, niin toisaalta, hyvä saada sellaistakin vertailukohtaa, että jos täällä tämmösetkin vaan porskuttaa, niin ei mulla ole mitään hävettävää, tai turhaan sitten pitää kynttilää vakan alla tai näin. (Kuntoutuja 8) 
Myönteisissä näköaloissa esiintyi myös puhetta muokattavista ulkoisista tai rakenteellisista tekijöistä (struktuurien muuttamista vaativa optimismi). Tällöin haastateltavat pohtivat erityisesti omaa elämäntilannetta, työkykyä ja preferenssejä työelämässä suhteessa reaalisiin työmahdollisuuksiin. Kuntoutujat saattoivat esimerkiksi kaivata itselle ja yleisesti työntekijöille lisää vaikutusmahdollisuuksia tai teknologisia sovelluksia, jotka edistäisivät vaikkapa työssä oppimista tai työn hakemista:

Toivoisi, että se teknologia kehittyisi, sovellukset siihen suuntaan, että se toimisi myöskin työnhakijoista sinne yrityksiin päin tukevasti. (Kuntoutuja 9)

Näköalaan liittyi myös ajatus rakenteiden muokkaamisen mahdollisuudesta. Esimerkiksi eräs haastateltava näki, että työolosuhteiden ja työn ehtojen tulisi olla joustavasti muokattavissa työntekijän tai työnhakijan tilanteen mukaan:

Niin, mutta mä ajattelen että mulle ehkä itselle sopisi semmonen, jos olisi enemmän vaikutusmahdollisuuksia. (Kuntoutuja 7)

Kuntoutujien kuvauksissa esiintyi myös epävarmuutta, vaikka näköala olisi samanaikaisesti toiveikas ja mahdollisuuksia painottava. Nimesimme tähän liittyvän epävarman optimismin omakohtaiseksi suunnanmuutosoptimismiksi. Työelämän rakenteet eivät olleet kuntoutujan näkökulmasta aina muokattavia, jolloin kuvauksissa korostui henkilön omien tekojen ja valintojen merkitys sekä suunnanmuutoksen tai perspektiivin vaihtamisen mahdollisuudet. Joissain tapauksissa aiempi työ ja ammatti olivat olleet henkilölle hyvin tärkeitä ja hän oli niihin sitoutunut, mutta työelämän olosuhteet olivat keskeisesti muuttuneet. Vaikka sidos ammatin toiminnan ehtoihin ja kontekstiin löystyi, se ei tarkoittanut toivon menettämistä. Mielessä saattoi olla uusi reitti, esimerkiksi suuntautuminen eri alalle:
- - ei ole aikaa enää sille, sen minkä takia on alunperin - vaan kaikkea muuta, ja just kun ryhmäkoot kasvaa, että välillä se on liikaa jo, että tuntuu, että sen takia mäkin mietin, pitäskö miettiä jotain alanvaihtoa, mutta auttaisko se sitten. Kaikilla aloilla on omat juttunsa. Ja sitten kun sydäntyö niin ei voi-, ja sitten mä mietin joku [muu ammatti] tai joku, mutta ei sillä oikein. Että parempi ehkä nyt toi, että parempi liksa vähän ehkä. Mutta muuten ihan hyvät oltavat 2018 Suomessa [naurahtaa], työelämässä. (Kuntoutuja 13)

Kuntoutujien puhe sisälsi myös muita kuin myönteisiä näköaloja. Niihin liittyi henkilökohtaista pohdintaa ja oman historian reflektointia, mutta myös työelämän yleistä kuvailua. Haastateltavalla saattoi esimerkiksi olla runsaasti työkokemusta ja pitkä työhistoria, mutta työn nykyiset vaatimukset tuntuivat työpaikkailmoitusten perusteella kohtuuttomilta. Ilmoituksissa haettiin joustavia "yli-ihmisiä", joiden vastakohdaksi asettuivat "tavalliset ihmiset ja työntekijät", joille ei näyttänyt olevan työelämässä tilaa. Työelämän odotukset suhteessa tavallisten työntekijöiden ominaisuuksiin korostuivat, ja tavallisuus toimi ikään kuin realistisena vastalauseena työelämän epärealistisille vaatimuksille:

Kun niitä lukee, on semmonen olo että pitäisi olla yli-ihminen, joka täyttäisi nuo. Että mähän olen ihan tavallinen [naurahtaa]. Ja niissä vaaditaan, se mitä sinulta odotetaan, niin odotetaan tätä ja tätä, ja melkein jokaisessa lukee "joustavuutta", joka tarkoittaa mun mielestä siinä työhakemuksessa, että sä olet valmis antamaan tälle firmalle kaikkesi - - Ja mä olen tottunut tekemään kyllä töitä. (Kuntoutuja 1)

Aina haetaan markkinoinnin rocktähteä ja huippuosaajaa [naurahtaa], ja sitten siis ajattelee, että tuskin sielläkään nyt mitään kahtakymmentä Elon Muskia teidän firmassa on töissä. (Kuntoutuja 8) 
Kuvauksissa nostettiin esiin myös sellaisia rakenteellisia esteitä, joihin vaikuttamisen mahdollisuudet koettiin pieninä. Näitä olivat esimerkiksi työntekijöiden kompetenssin tunnistamisen estävät työkulttuurin piirteet. Eräs haastateltava pohti johtajalähtöistä työn organisointia suomalaisen työelämän ominaispiirteenä. Tämä työn organisointitapa asettui osaltaan myös työelämään liittyvän optimistisen näköalan esteeksi. Haastateltava näki johtajalähtöisen työkulttuurin vaihtoehdoksi työn tekemisen tavan, jossa työntekijällä on vapautta suhteessa työhön ja sen tuloksiin. Joissain haastatteluissa viitattiin vallitsevaan työkulttuuriin ahtaana tilana, jossa kuntoutujan kompetenssia ei havaita ja hyödynnetä. Lisäksi haastateltavat pohtivat työelämän kovia vaatimuksia, muutosta, kilpailuasetelmaa ja työuupumusta. Tässä kontekstissa oma asema työmarkkinoilla määrittyi erityisen epävarmaksi. Seuraavassa haastatteluotteessa kuntoutuja käsittelee työelämän ja yhteiskunnan asenteellisuutta. Tilanne sisältää yhtäaikaisesti useita epävarmuuksia, eikä henkilön ole mahdollista kokea selkeää myönteistä yhteenkuuluvuutta työelämään osallistuvien kanssa. Halu olla mukana epävarmassa, työuupumusriskejä sisältävässä, syyllistävässä työelämässä onkin osatyökykyisen tilanteessa altis hiipumaan:

Että kun ei ole aivan kuitenkaan täysin työkykyinen niin, miten se sitten, siinä sitten kilpailla sellaisten kanssa, jotka vaikka paremmalla osaamisellakin tai enemmällä työkokemuksella on työttömänä niin, ei ole sitten oikein helppoa siinä olla. Ja muutenkin [tauko 9 s.] monelta taholta tulee, aika kovaa tekstiä työttömien suuntaan, että kaikki nämä aktiivimallit ja muutenkin, niin se sellainen ilmapiiri tuntuu olevan, että paljon työttömiä syyllistetään. (Kuntoutuja 11)

Hieman myöhemmin haastattelussa kuntoutuja kertoo ristiriitaisesta halustaan olla mukana työelämässä. Työelämää koskevat havainnot ovat lisänneet hänen epävarmuuttaan työelämään osallistumisen mielekkyydestä:
- - sitten vähän sellaistakin ristiriitaa, että kun, onko se sitten uutisointia vai mitä, että kuinka monessa työssä niin kiireistä on, että sitten monet siinä ihan palaa loppuun. Sellainen ristiriita, että kuinka paljon itse edes haluaa sitten sellaiseen mukaan, että muuttuuko se sitten, muuttuisiko se sellaiseksi sitten. (Kuntoutuja 11)

Kuntoutujilla esiintyi myös työelämään liittyvän näköalan puuttumista tai kuvailun vaikeutta. Näissä tapauksissa haastateltavat eivät pystyneet tai halunneet vastata kysymykseen siitä, millaisena he työelämän näkevät. Erään kuntoutujan mukaan asiaa on vaikea miettiä, kun ei ole ollut "oikeissa" töissä. Kysymykset työelämän luonteesta voivatkin tuntua hyvin kaukaisilta, jos oma kokemus ja kosketuspinta työelämään on vähäistä.

\section{Omaohjaajien korostunut huoli osatyökykyisistä}

Työllistymistä edistävän ammatillisen kuntoutuksen omaohjaajat eivät juurikaan pohtineet omaa subjektiivista asemaansa työelämässä, vaan enemmänkin osatyökykyisten asemaa sekä osaamisen ja työkyvyn kysymyksiä. Erityistä oli, että osatyökykyisyyteen liittyvä huolipuhe korostui. Miltei kaikki omaohjaajat kuvailivat erityisen painokkaasti kuntoutujien vaikeaa asemaa työelämässä. Omaohjaajien kuvaukset sisälsivät huolta kuntoutujien asemasta, työmarkkinoiden polarisoitumisesta, työn vaatimuksista sekä kuntoutuksen ja kuntoutujien olosuhteista työpaikoilla. Lisäksi huoli liittyi rakenteellisiin ratkaisuihin työpaikoilla ja yhteiskunnassa. Omaohjaajien myönteisissä näköaloissa esiintyi kuitenkin myös optimismia: ensinnäkin työnantajiin ja heidän asenteisiinsa liittyvää optimismia (työnantajaoptimismia) ja toiseksi asennemuutosoptimismia.

Työmarkkinoiden polarisoituminen huolestutti omaohjaajia. Kuten kuntoutujien, myös omaohjaajien haastatteluissa tuli selkeästi esiin jako hyvin työelämässä selviytyvien ja 
muiden välillä. Joidenkin haastateltavien mukaan työhön liittyvät vaatimukset olivat hyvin selviytyville ja korkean koulutuksen omaaville mahdollisia täyttää, mutta heikommassa asemassa oleville jopa mahdottomia. Kuntoutujien tapaan myös omaohjaajat viittasivat siihen, miten työpaikkailmoituksissa saatetaan etsiä "yli-inhimillisiä", täydellisen työkyvyn omaavia osaajia aivan tavallisiin tehtäviin. Omaohjaajat näkivät myös työkyvyn työelämän vaatimusten kannalta hyvin polarisoituneena; työssä ollaan joko täysin työkykyisiä tai työelämässä ei olla lainkaan mukana.

Pelkästään kun lukee noita työpaikkailmoituksia, jotka on julkisessa haussa, niin kyllä ne meidän asiakkaita oikeesti, ne pelottaa ja säikäyttää koska siellä ne viestii sitä, että tarvitaan suurin piirtein semmosta yli-inhimillistä olentoa johonkin tosi vaatimattomaankin paikkaan. (Omaohjaaja 25)

Omaohjaajat osallistuvat kuntoutukseen liittyviin työpaikkapalavereihin, ja he kuvailivat nähneensä niissä hyvin erilaisia työnantajia ja kuntoutuksen työympäristöjä. Eräs omaohjaaja kertoi palaverista, jossa työpaikalla koettu kuormitus ja työnantajan kiire kulminoituivat lopulta siihen, että työnantaja jättäytyi kokonaan palaverista pois. Tilanteen kohtasi myös omaohjaajan asiakkaana ollut kuntoutuja. Tapahtumat olivat saaneet epäilemään, onko palvelu ja työkokeilu tämän kaltaisessa ympäristössä ja olosuhteissa oikeastaan edes kuntoutujalle hyväksi:

Onko se hänelle kuntouttavaa, vaikka hän sinne pääsisikin, jos se tahti on kova ja vaatimukset hirveet ja työnantaja ei ole läsnä edes niissä pienissä palavereissa? Välillä huolettaa, kovastikin. (Omaohjaaja 28)

Omaohjaajien haastatteluissa osatyökykyisten työympäristöön liittyvä huolestuneisuus koskikin erityisesti työpaikkojen olosuhteita sekä niiden haastavuutta kuntoutujille. Tietyt työympäristöt, työn vaatimukset ja työn tekemisen reunaehdot nähtiin osatyökykyisille erityisen vaikeina. Omaohjaajat kuvailivat esimerkiksi työn kuormittavuutta ja stressaavuutta, kiirettä ja työntekijöiden vaihtuvuutta. Eräs haastateltava pohti erityisesti mielenterveysongelmiin liittyviä kysymyksiä ja toi esiin huolen siitä, miten kuormittavat työympäristöt vaikuttavat jo aiemmin uupumusta kokeneisiin kuntoutujiin.

Omaohjaajat olivat huolissaan myös yleisestä yhteiskunnallisesta tilanteesta ja työttömien ohjaamiseen liittyvistä poliittisista ratkaisuista. Työkykyvaikeuksien lisäksi omaohjaajien asiakkaat olivat kohdanneet muun muassa työttömyysturvan aktiivimalliin liittyviä vaatimuksia ja toimeentulon epäselvyyksiä, jotka aiheuttivat lisäkuormitusta ja lisäsivät tulevaisuutta koskevaa epävarmuutta. Eräs haastateltu omaohjaaja näki erityisen vaikeana niiden kuntoutujien tilanteen, jotka eivät pysty kouluttautumaan uudelleen eivätkä saa eläkettä, mutta joiden työkyky on todella heikko:

Ja sitten nimenomaan suurimmat haasteet on näillä, ketkä ei pysty uudelleenkouluttautumaan, niin heidän sitä ammatillisen tulevaisuutta, että miten tehdään heidän kanssa. Jos siellä ei ole semmoista, ne sairaudet, vammat ei riitä siihen, että sieltä eläkekriteeristö täyttyisi, niin mikä on heidän tulevaisuus sitten, että - - siellä työttömänä ja sitten on kaikki uudet aktiivimallit ynnä muuta. Että vähän huoli heidän tulevaisuudesta on kyllä. (Omaohjaaja 31)

Omaohjaajienkaan näköaloja ei kuitenkaan voida pitää toivottomina, sillä omaohjaajat pohtivat toistuvasti rakenteellisten ratkaisujen tarvetta ja ratkaisuja. Haastatellut omaohjaajat miettivät erilaisia ratkaisukeinoja, kuten välityömarkkinoiden luomista ja taloudellisten tukien sujuvoittamista. Omaohjaajat painottivat, että taloudellinen toimeentulo tulisi turvata joustavasti myös kuntoutuspalveluiden aikana:

Että jollain lailla mä haluaisin sitä välityömarkkinaa enemmän, että meillä olisi sitä 
semmoista työtä, että mahdollistettais niiden vähän alentuneella työkyvyllä olevien ihmistenkin työllistyminen. Ettei tämä olisi vähän niin kuin kilpa-ajoissa, että isommalla moottorilla mennään kovempaa. (Omaohjaaja 20)

Ihmiset koko ajan hermoilee niiden rahojensa kanssa. Se on semmoinen, että siihen pitäisi joku keksiä. Mutta ehkä tulee joku perustoimeentulo joskus, niin ratkeaa nämäkin ongelmat. (Omaohjaaja 23)

Kahden omaohjaajan haastattelut sisälsivät selkeästi osatyökykyisten tilanteeseen liittyvää optimismia. Omaohjaajat pohtivat erityisesti työnantajia ja heidän asenteitaan. Kumpikin haastateltava kertoi kohdanneensa työnantajia, joiden asenne osatyökykyistä työnhakijaa kohtaan oli ollut myönteinen tai muuttunut palveluun osallistumisen myötä myönteiseen suuntaan. Kutsumme tällaista optimismia työnantajaoptimismiksi. Vaikka työelämän olosuhteet nähtiin haasteellisina, haastateltavien mukaan on olemassa myös sosiaalisuutta sekä työyhteisöjä ja työnantajia, joissa suhtaudutaan avoimesti ja huomioon ottavasti kaikenlaiseen työhön osallistumiseen, myös osatyökykyisyyteen. Tämä vaatii kuitenkin mahdollisten ongelmien avointa käsittelyä. Seuraavaksi siteeratun haastateltavan mukaan uskallus kertoa esimerkiksi sairauksista edistää sujuvaa suhdetta työnantajan ja työntekijän tai kuntoutujan välillä:

On sosiaalisiakin yrittäjiä ilman sitä varsinaista virallista sosiaalisen yrittäjän statusta. Jotenkin se sairaus ei ole enää työnantajille niin suuri este ja mörkö. Ne osataan huomioida nykypäivänä paremmin työyhteisöissä kuitenkin kuin esimerkiksi kymmenenkin vuotta sitten, kun asioista uskalletaan ja osataan puhua niiden oikeilla nimillä. (Omaohjaaja 19)

Lisäksi omaohjaajat näkivät, että työnantajien asenteet voivat kokemuksen myötä muuttua. Asennemuutosoptimismissa korostui kokemuksen merkitys asenteiden muuttumisessa. Kun työnantajat saavat kokemusta kuntoutujista työpaikoilla, saattaa heidän asenteensa muuttua aiempaa myönteisemmäksi. Omakohtainen kokemus osatyökykyisten kohtaamisesta ja erilaisten työntekijöiden osallistumisesta työhön ja työyhteisöön nähtiin muutoksen mahdollistajana:

Esimerkiksi näissä työharjoitteluissa näkee sen, että todennäköisesti työnantaja ei uskalla palkata sitten sitä samaa osatyökykyistä henkilöä heille suoraan töihin, mutta kun se näkee työharjoittelussa sen henkilön, niin se uskaltaa sen sitten jopa, että se pystyy tekemään sitä työtä, niin työnantajat on uskaltanut sitten palkatakin vaikka osa-aikatyöhön määräajaksi sen jälkeen. (Omaohjaaja 31)

\section{Työnantajien puhe osatyökykyisistä, yrittäjyydestä ja ratkaisuista}

Työnantajien haastatteluista oli paikannettavissa subjektiivisesti painottuneita, mutta myös yleisesti työelämään liittyviä näköaloja. Muu kuin myönteinen puhe koski esimerkiksi työmarkkinoiden toimintaa. Se sisälsi pohdintaa erityisesti osatyökykyisten asemasta työelämässä sekä työelämän ja työmarkkinoiden polarisoitumisesta ja eriarvoistumisesta. Työnantajat esittivät kuitenkin myös työelämän rakenteisiin tai työnantajiin itseensä liittyviä ratkaisuja. Myönteisten näköalojen osalta työnantajien puheesta hahmottui omakohtaista yrittäjä- tai työtehtäväkeskeistä optimismia (omakohtainen yrittäjäoptimismi) sekä asenteiden ja työpaikkakulttuurien muutokseen liittyvää optimismia (asennemuutosoptimismi).

Kuten kuntoutujien ja omaohjaajien, myös työnantajien puhe sisälsi työmarkkinoiden polarisoitumisen ja eriarvoistumisen kuvauksia. Työelämä näyttäytyi siellä selviytyvien kannalta myönteisenä, mutta samanaikaisesti kiihtyvä työtahti ja työelämän kovuus asettivat osan ihmisistä vaikeaan asemaan. Kuten omaohjaajien, myös työnantajien puheessa työ ja työelämän olosuhteet kuvattiin toisen - erityisesti osatyökykyisen, kuntoutujan tai 
muulla tavalla työelämässä heikommassa asemassa olevan - näkökulmasta haasteellisina. Tilanteeseen saatettiin etsiä rakenteellisia ratkaisuja. Työnantajat pohtivat esimerkiksi sellaisten työpaikkojen luomista, joissa kosketus työelämään tapahtuisi pehmeämmin ja joissa olisi mahdollisuus tarjota riittävästi tukea:

Mun mielestä semmonen, valitettavasti tämmönen eriarvoistuminen alkaa näkyä meidän työelämässä, että tämmöset pärjääjät pärjää ja tämmöset ei-pärjääjät ei valitettavasti sitten pärjää. Että hyvin on tämmönen kova tämä työelämä ja ihmisiltä vaaditaan, tämä työelämän tahti on tosi kova, ja tuntuu vaan että kiihtyy koko ajan, ja mulla esimerkiksi on suuri huoli näistä tämmösistä niin sanotuista putoajista, että kuinka he pysyvät kelkassa mukana. Että kyllä me tarvitaan tämmösiä, jotenkin tämmösiä pehmeämpiäkin paikkoja ja semmosta ohjauksellista tukea ja muuta, että me saatais kaikille mahdollisuus tähän työhön. (Työnantaja 41)

Työnantajat nostivat esiin myös muita muutosta tai ratkaisuja vaativia seikkoja. Yksi näistä liittyi siihen, miten työnantajia voitaisiin paremmin tukea osatyökykyisten palkkaamisessa. Haastateltavat korostivat yrittäjille tarjottavien tukien ja palkkatukijärjestelyjen mahdollisuuksia. Tärkeää näytti olevan myös yhteinen, osatyökykyisten voimavarojen käyttöön liittyvä päämäärä. Voimavarojen hyödyntämiseen kaivattiin yhteiskunnallisia ratkaisuja, kuten osaaikatyöllistämisen tukemista sekä työn tuottavuuden ja yrittäjälle jäävän katteen turvaamista:

Siinä mielessä, että työnantajat saisivat enemmän tukea siinä vielä, että ne voisi ottaa työntekijät töihin, joilla on kyllä voimavaraa mutta ei kai koko työpäivää, kahdeksantuntinen vaan se voisi olla kuustuntinen tai viistuntinen. (Työnantaja 44)

Ja se, että silloin kun mietitään näitä tuettuina työllistettäviä, niin se, että kaikki menee siihen työllistämiseen, eikä yhtään tule yritykseen, niin se on yksi asia miksi niitä ei haluta ottaa. Se on kuitenkin se, että yrityksen toiminta perustuu siihen, että se kannattaa ja tuottaa voittoa. (Työnantaja 48)

Työnantajien myönteisyys liittyi myös työelämän ja yrittäjyyden dynaamisuuteen sekä haastateltavien omien organisaatioiden, työntekijöiden ja työyhteisöjen mahdollisuuksiin. Tällaisen optimismin nimesimme omakohtaiseksi yrittäjä- ja työtehtäväkohtaiseksi optimismiksi. Eräs haastateltava näki esimerkiksi "työelämän tahdin kiihtymisen" henkilökohtaisesta yrittäjän roolista käsin myönteisenä. Tahdin kiihtyminen ei työnantajan näkökulmasta ollut kielteistä tai liiallista, vaan kuvasi myönteistä liikettä eli dynaamisuutta työelämässä:

Sanotaan näin, että tahti kiihtyy. Kyllä mä näen sen ihan positiivisena, että mun mielestä nyt näin yrittäjän näkökulmasta ollaan menty parempaan suuntaan. Kyllä mä olen ihan tyytyväinen kaikkiin näihin mun työntekijöihinkin. Täytyy olla ihan kiitollinen, että on tämmönen systeemi ja paketti meillä ja muutoin Suomessa työelämää ajatellen, kyllä mä näen sen ihan valoisana. Onhan työttömyyskin vähentynyt nyt tosi paljon ja pahin ahdinko alkaa olla takana. (Työnantaja 38)

Työnantajat pohtivat suomalaista työelämää myös omista henkilökohtaisista asemistaan käsin. He esimerkiksi arvostivat oman työnsä erityispiirteitä. Oman työn ja työyhteisön tietyt ominaisuudet, kuten luovan suunnittelun mahdollisuus, synnyttivät myönteisiä odotuksia ja tulevaisuuden mahdollisuuksia. Työnantajien näköalat sisälsivät myös käsityksiä siitä, että työelämässä tapahtuvan muutoksen tulisi olla myönteistä kaikkien työelämän osapuolten kannalta. Tämän kaltainen optimismi liittyi asenteiden ja työpaikkakulttuurien muutokseen. Erään haastateltavan mukaan esimerkiksi autoritaarisen johtamiskulttuurin tulisi muuttua. Hän toivoi matalien hierarkioiden organisaatiorakenteita tukevaa muutosta, jossa työkokeilijoiden 
ja muiden osatyökykyisten asema työpaikalla kehittyisi nykyistä tasavertaisemmaksi:

Jotenkin katsoo tätä yhteiskunnan johtamista, niin välillä tuntuu, että jossain me ollaan, siinä 50-60-luvulla, vielä hyvin tämmösissä autoritaarisessa systeemissä. Ehkä sen näkökulmasta, että siihen tulisi panostaa enemmän. Silloin liittyen tähän, on se sitten työkokeilussa, työvalmennuksessa tai palkkatukityössä tai ihan vakinaisessa työssä oleva, niin se semmoinen mentaliteetti ja kaikki se muuttuisi. (Työnantaja 43)

\section{Eri osapuolten näköalat ja optimismin muodot}

Edellä esiteltiin ammatillisen kuntoutuksen eri osapuolten eli kuntoutujien, omaohjaajien ja työnantajien näköaloja työelämään. Kaikkien osapuolten näköaloissa esiintyi työelämään liittyvää myönteisyyttä ja kuvauksista oli tunnistettavissa erilaisia optimismin muotoja. Erityisesti omaohjaajilla korostui kuitenkin myös osatyö- kykyisyyteen liittyvä huolipuhe. Osapuolilla oli myös yhteisiä huolenaiheita, kuten työmarkkinoiden polarisoituminen ja osatyökykyisten haasteellinen asema työmarkkinoilla. Kuntoutujat puhuivat työelämästä joko hyvin omakohtaisesta tai laajemmasta työntekijänäkökulmasta käsin. Omaohjaajat puolestaan pohtivat tulevaisuuden työelämää runsaasti osatyökykyisten eli asiakkaidensa näkökulmasta. Työnantajien puheessa korostui yrittäjä- ja organisaatiokeskeisyys.

Myönteisistä näköaloista hahmottui myös erilaisia optimismin muotoja, jotka esitetään tiivistetysti taulukossa 2. Optimismia esiintyi aineistossa ensinnäkin suhteessa rakenteellisiin reunaehtoihin, kuten asenteisiin ja työkulttuureihin, sekä niihin liittyvään muutospotentiaaliin (esim. muutosvaatimusoptimismi, asennemuutosoptimismi). Lisäksi aineistossa esiintyi optimismia suhteessa omien valintojen ja toiminnan mahdollisuuksiin. Kuntoutujat pohtivat esimerkiksi haasteiden edessä alan vaihtoa ja muuta uuden suunnan löytämistä (suunnanmuutosoptimismi).

\section{Taulukko 2. Ammatillisen kuntoutuksen osapuolet, näköalat ja optimismin muodot}

\begin{tabular}{l|l}
$\begin{array}{l}\text { Ammatillisen kuntoutuksen } \\
\text { osapuolet ja näköalat aineistossa }\end{array}$ & Optimismin muodot \\
\hline $\begin{array}{l}\text { Kuntoutujat: } \\
\text { omakohtainen ja työntekijäkeskeinen } \\
\text { näköala }\end{array}$ & $\begin{array}{l}\text { - omakohtainen kompetenssioptimismi } \\
\text { - muutosvaatimusoptimismi, erityisesti työntekijöitä palvelevat } \\
\text { rakenteelliset muutokset } \\
\text { - suunnanmuutosoptimismi, erityisesti omaan elämään liittyvät valinnat }\end{array}$ \\
$\begin{array}{l}\text { Omaohjaajat: } \\
\text { osatyökykyisyyskeskeinen näköala }\end{array}$ & $\begin{array}{l}\text { työnantajaoptimismi, erityisesti positiivisiksi koetut työnantajat ja } \\
\text { työyhteisöt }\end{array}$ \\
\hline $\begin{array}{l}\text { Työnantajat: } \\
\text { yrittäjä- ja organemuutosoptimismi, erityisesti työnantajien asenteiden } \\
\text { näköala }\end{array}$ & $\begin{array}{l}\text { muuttuminen } \\
\text { omakohtainen yrittäjäoptimismi }\end{array}$ \\
\hline
\end{tabular}


Kaikkien osapuolten haastatteluissa pohdittiin rakenteellisten tekijöiden merkitystä, kuten rekrytointikäytäntöjä, työ- ja organisaatiokulttuureja sekä työnantajien asenteita. Rakenteellisiin tekijöihin liittyi sekä uskoa muutoksen mahdollisuuteen että erilaisia huolia. Tulkitsemmekin, että tämän kaltainen toiveikas avoimuus voidaan ymmärtää Schneiderin (2001) tapaan realistisena optimismina. Tällöin olennaisia eivät ole pelkästään yksilölliset ratkaisut, kuten vaihtoehtoisten reittien näkeminen, vaan myös konkreettiset tilannetekijät sekä ympäristö (esimerkiksi yhteiskunta- ja työpaikkakonteksti). Realistisessa optimismissa suuntaudutaan tulevaisuuteen toiveikkaasti, mutta kyetään välttämään hyvin epärealistisia suunnitelmia. Myös huolet ja epävarmuus voivat kuulua realistiseen optimismiin silloin, kun ne eivät muserra toiveikkuutta vaan auttavat toimimaan sopivasti mahdollisuuksien edessä. Schneiderin (emt.) mukaan realistinen optimismi onkin taipumusta säilyttää myönteinen näkökulma samalla kun fyysisen ja sosiaalisen maailman rajoitukset otetaan huomioon. Tämä ei tarkoita luovuttamista, vaan avautumista elämään sellaisissa puitteissa, joissa voimme valita rajoitteista huolimatta myönteisiä näkökulmia.

\section{Pohdinta}

Kuntoutumisen ja työelämään palaamisen prosessit voivat olla henkilökohtaisesti hyvinkin pitkiä ja haastavia (Ståhl \& Edvardsson 2014). Osa työikäisestä väestöstä sijoittuu työkykyongelmien vuoksi jatkuvasti työelämän ulkopuolelle, ja kuntoutuksen keinot edistää työelämään palaamista ovat rajalliset. Työelämään osallistuminen ei toteudukaan kaikkien väestöryhmien kohdalla tasavertaisesti, ja osatyökykyisten työllisyys on ollut Suomessa heikompaa kuin muilla työikäisillä (Asplund \& Koistinen 2014, 100-101). Osatyökykyisten vaikeasta asemasta huolimatta ammatillisen kuntoutuksen osapuolten puheessa esiintyi myönteisiä, suomalaiseen työelämään ja sen tulevaisuuteen liittyviä näköaloja. Myönteisyys ilmeni toiveikkuutena, luottamuksena tulevaan sekä uskona muutoksen ja tasavertaisuuden mahdollisuuteen.

Myönteisillä ja tasavertaisilla tulevaisuuden mahdollisuuksilla oli kuitenkin rakenteellisia ja kulttuurisia reunaehtoja. Kuntoutujat korostivat esimerkiksi vaikutusmahdollisuuksien tärkeyttä sekä työntekijänäkökulman huomioimista työmarkkinoilla. Työnantajien puhe sisälsi sekä subjektiivista yrittäjyyteen ja työpaikkoihin liittyvää optimismia että ratkaisukeskeistä pohdintaa osatyökyisten asemasta työelämässä. Erityisesti kuntoutuksen omaohjaajat näkivät työelämän osatyökykyisten kuntoutujien - eli oman asiakasryhmänsä - kannalta myös huolestuttavana. Toivottomina kuvauksia ei kuitenkaan voida pitää, sillä niihin sisältyi ratkaisujen pohdintaa. Kuntoutuksen osapuolten puheissa esiintyvä optimismi kuvautuukin realistisena optimismina (vrt. Schneider 2001).

Kuntoutuspalveluissa toivo ja luottamus tulevaan ovat tärkeitä erityisesti kuntoutusmotivaation syntymisessä (esim. Onken ym. 2007; Snyder 2002). Toivon herättämiseen osana kuntoutuspalveluja liittyy myös kuntoutuseettisiä kysymyksiä. Moraalisesti arveluttavaa on toivon herättäminen tilanteessa, jossa realistisia mahdollisuuksia työhön osallistumiselle ja työelämässä selviytymiselle ei todellisuudessa kyetä tarjoamaan tai luomaan. Russinovan (1999) mukaan on tärkeää, että kuntoutusammattilainen sietää tulevaisuuden epävarmuutta. Ammattilainen joutuu väistämättä sietämään sitä, ettei hän varmuudella tiedä, onnistutaanko kuntoutuksessa ja ovatko kuntoutuksen seuraukset myönteisiä. Tähän liittyy myös kuntoutuksen vaikutusmekanismeja koskevaa epävarmuutta (vrt. Schneider 2001). Ammattilaisten kyky rohkaista toiveikkuutta saattaa kuitenkin olla myönteisten tulosten kannalta olennaista (ks. Wong 2015). Toisaalta toiveikkuus ei ole aina sidoksissa esimerkiksi työllistymiseen (esim. Waynor \& Gill 2015). Ammatillisessa kuntoutuksessa onnistuminen liittyykin myös vaikeasti hallittavaan yhteiskunnalliseen ja sosiaaliseen kontekstiin 
eli työmarkkinoihin ja työelämään. Tämä tekee työhönkuntoutuksesta ja kuntoutusammattilaisten työstä omalla erityisellä tavallaan haastavaa.

Ammatillisen kuntoutuksen yhteiskunnallisena tavoitteena on luoda sellaisia ratkaisuja, jotka parantavat osatyökykyisten työkykyä ja asemaa työmarkkinoilla. Tämän tutkimuksen tulosten perusteella ratkaisujen kehittämisessä tulisi ottaa huomioon kuntoutuksen koko toimintaympäristö, kuten työpaikat, joissa erityisesti työllistymistä edistävä ammatillinen kuntoutus tapahtuu. Tällä hetkellä ei ole vielä riittävästi tietoa niistä tekijöistä, jotka edesauttavat realistisen optimismin syntymistä ja ylläpitämistä osana ammatillista kuntoutusta. Jatkossa tulisi tarkastella kriittisesti myös sitä, onko realistinen optimismi yhteydessä

\section{Kirjallisuus}

Asplund, R. \& Koistinen, P. (2014) Onko työmarkkinoilla tilaa kaikille? Katsaus erityisryhmiin kohdistetun politiikan tuloksiin ja haasteisiin. Työ- ja elinkeinoministeriön julkaisuja. Helsinki: Työ- ja elinkeinoministeriö.

Bloester, C. \& Stahl, T. (2017) Hope. Teoksessa E. N. Zalta (toim.) The Stanford Encyclopedia of Philosophy (Spring 2017 Edition). [online]. <URL:https://plato.stanford.edu/archives/ spr2017/entries/hope/>. Luettu 12.2.2020.

Bryant, F. \& Cvengros, J. (2004) Distinguishing hope and optimism: two sides of a coin, or two separate coins? Journal of Social and Clinical Psychology 23 (2), 273-302. https://doi.org/10.1521/jscp.23.2.273.31018

Gustafsson, J., Peralta, J. \& Danermark, B. (2018) Supported employment and social inclusion - Experiences of workers with disabilities in wage subsidized employment in Sweden. Scandinavian Journal of Disability Research 20 (1), 26-36. https://doi.org/10.16993/sjdr.36

Haapakoski, K., Åkerblad, L., Tolvanen, A. \& Mäntysaari, M. (2020) Kelan työllistymistä edistävä ammatillinen kuntoutus. Palvelun toimivuuden edellytykset. Sosiaali- ja terveysturvan raportteja 22. Helsinki: Kela.

Hirschi, A., Abessolo, M. \& Froidevaux., A. (2014) osatyökykyisten omien työelämätavoitteiden toteutumiseen.

\section{Kiitokset}

Kiitämme Kelaa tutkimusrahoituksesta.

\section{Kirjoittajat}

Kaisa Haapakoski, YTT, tutkijatohtori, Jyväskylän yliopisto, sähköposti: kaisa.haapakoski@jyu.fi Leena Åkerblad, YTT, tutkijatohtori, Jyväskylän yliopisto, sähköposti: leena.akerblad@jyu.fi

Hope as a resource for career exploration: Examining incremental and cross-lagged effect. Journal of Vocational Behavior 86 (1), 38-47. https://doi.org/10.1016/j.jvb.2014.10.006 Järvikoski, A. (2013) Monimuotoinen kuntoutus ja sen käsitteet. Sosiaali- ja terveysministeriön raportteja ja muistioita 2013:43. Helsinki: Sosiaalija terveysministeriö.

Kela (2015) Muutos-hanke. [online]. <URL:https:// www.kela.fi/muutos-hanke>. Luettu 20.6.2019.

Kela (2016) Kelan avo- ja laitosmuotoisen kuntoutuksen standardi. Työllistymistä edistävä ammatillinen kuntoutus. [online]. <URL:https:// www.kela.fi/documents/10180/2826255/stnd tk.pdf>. Luettu 20.6.2019.

Kirjoittajakollektiivi (2017) Jälkisanat: työmarkkinoiden riskiryhmät. Teoksessa P. Pyöriä (toim.) Työelämän myytit ja todellisuus. Gaudeamus: Helsinki, 197-202.

Kotkavirta, J. (2000) Toivo, luottamus ja identiteetti. Teoksessa J. Kotkavirta \& A. Tuomi (toim.) Toivo ja luottamus epävarmuuksien maailmassa. Filosofisia ja teologisia puheenvuoroja. Jyväskylä: SoPhi, 5-17.

Kronström, K., Karlsson, H., Nabi, H., Oksanen, T., Salo, P., Sjösten, N., Virtanen, M., Pentti, J., Kivimäki, K. \& Vahtera, J. (2011) Optimism and pessimism as predictors of work disability with a 
diagnosis of depression: A prospective cohort study of onset and recovery. Journal of Affective Disorders 130 (1-2), 294-299.

https://doi.org/10.1016/j.jad.2010.10.003

Laiho, V., Hopponen, A., Latvala T., Rämö A. (2010) Erityisryhmien työkyky - työttömät ja vammaiset. Helsinki: Pellervon taloustutkimus.

Laki Kansaneläkelaitoksen kuntoutusetuuksista ja kuntoutusrahaetuuksista 2005/556. [online]. <URL:https://www.finlex.fi/fi/laki/ajantasa/2005/20050566>. Luettu: 2.3.2020.

Leeman, L., Isola, A., Kukkonen, M., Puromäki, H., Valtari, S. \& Keto-Tokoi, A. (2018) Työelämän ulkopuolella olevien osallisuus ja hyvinvointi. Kyselytutkimuksen tuloksia. Työpaperi 17:2018. Helsinki: Terveyden ja hyvinvoinnin laitos.

Lydell, M., Hildingh, C., Månasson, J., Marklund, B. \& Grahn, B. (2011) Thoughts and feelings of future working life as a predictor of return to work: a combined qualitative and quantitative study of sick-listed persons with musculoskeletal disorders. Disability and Rehabilitation 33 (13-14), 1262-1271.

https://doi.org/10.3109/09638288.2010.527029

O'Connor, R. \& Cassidy, C. (2007) Predicting hopelessness: The interaction between optimism/ pessimism and spesific future expectancies. Cognition \& Emotion 21 (3), 596-613.

https://doi.org/10.1080/02699930600813422

Onken, S., Craig, C., Ridgway, P., Ralph, R. \& Cook, J. (2007) An analysis of the definitions and elements of recovery: a review of the literature. Psychiatric Rehabilitation Journal 31 (1), 9-22. https://doi.org/10.2975/31.1.2007.9.22

Porter, S., Lexén, A., Johanson, S. \& Bejerholm, U. (2018) Critical factors for the return-to-work process among people with affective disorders: Voices from two vocational approaches. Work 60 (2), 221-234.

https://doi.org/10.3233/WOR-182737

Russinova, Z. (1999) Providers' hope-inspiring competence as a factor optimizing psychiatric rehabilitation outcomes. Journal of Rehabilitation 65 (4), 50-57. https://doi.org/10.2975/34.3.2011.177.185

Santilli, S., Marcionetti, J., Rochat, S., Rossier, J. \& Nota, L. (2017) Career adaptability, hope, optimism, and life satisfaction in Italian and Swiss adolescents. Journal of Career Development 44 (1), 62-76. https://doi.org/10.1177/0894845316633793
Scheier, M. F. \& Carver, C. S. (1985) Optimism, coping, and health: Assessment and implications of generalized outcome expectancies. Health Psychology 4 (3), 219-247.

https://doi.org/10.1037/0278-6133.4.3.219

Scheier, M. F., Carver, C. S. \& Bridges M. F. (1994) Distinguishing optimism from neuroticism (and trait anxiety, self-mastery, and self-esteem): a reevaluation of the Life Orientation Test. Journal of Personality \& Social Psychology 67 (6), 1063-78. https://doi.org/10.1037/0022-3514.67.6.1063

Schneider, S. (2001) In search of realistic optimism. Meaning, knowledge, and warm fuzziness. American Psychologist 56 (3), 250-263. https://doi.org/10.1037/0003-066X.56.3.250

Seing, I., MacEachen, E., Ståhl, C. \& Ekberg, K. (2015) Early-return-to-work in the context of an intensification of working life and changing employment relationships. Journal of Occupational Rehabilitation 25 (1), 74-85. https://doi.org/10.1007/s10926-014-9526-5

Seligman, M. (1990) Optimistin käsikirja. Helsinki: Otava.

Ståhl, C. \& Edvardsson Stwine, E. (2014) Narratives of sick leave, return to work and job mobility for people with common mental disorders in Sweden. Journal of Occupational Rehabilitation 24 (3), 543-554. https://doi.org/10.1007/s10926-013-9480-7

Snyder, C. R. (2000) Handbook of Hope: Theory, Measures, and Applications. San Diego: Academic Press. https://doi.org/10.1207/S15327965PLI1304_01

Snyder, C. R. (2002) Hope theory: Rainbows of the mind. Psychological Inquiry 13 (4), 249-275. https://doi.org/10.1207/S15327965PLI1304_01 Törrönen, J. (2010) Identiteettien ja subjektiasemien analyysi haastatteluaineistossa. Teoksessa J. Ruusuvuori, P. Nikander \& M. Hyvärinen (toim.) Haastattelun analyysi. Tampere: Vastapaino, 180-211.

Waynor, W. \& Gill, K. (2015) The role of hope in predicting supported employment success. Journal of Rehabilitation 81 (2), 26-31.

Wong, J. (2015) The psychology of encouragement: Theory, research and applications. The Counseling Psychologist 43 (2), 178-216.

https://doi.org/10.1177/0011000014545091

Youssef, C. \& Luthans, F. (2007) Positive organizational behavior in the workplace. The impact of hope, optimism, and resilience. Journal of Management 33 (5), 774-800.

https://doi.org/10.1177/0149206307305562 